\title{
The Academic Library within a National Information Policy: Introduction
}

$\mathbf{T}$

HE FOLLOWING PAPERS were presented during the 1978 Annual Conference of the American Library Association in Chicago at a program of the Association of College and Research Libraries. The theme of the program was: The Academic Library within a National Information Policy-Toward the White House Conference and Beyond. Each speaker was urged to approach the topic from his or her individual professional perspective, focusing on issues that seemed particularly critical or meaningful on the basis of that perspective.

The papers clearly express a wide range of views on this very complex topic. They also raise, I believe, some critical and incisive issues with regard to academic libraries and a national information policy.

Richard M. Dougherty views the prospect of a national information policy from the perspective of the major research library. After identifying a number of difficulties and hazards, he suggests that a national information policy should be explored, but with extreme caution.

Irma Y. Johnson brings a "science and technology" focus to bear on the issue. Persuasively arguing that academic libraries are

Eldred R. Smith is director of libraries, University of Minnesota, Minneapolis. He was president of the Association of College and Research Libraries in 1977-78. presently subsidizing the exchange of scientific information, particularly, the results of research supported by government contracts, she asserts that the national interest would be much better served if this process were federally funded also. She sees such a development as an essential and fundamental cornerstone of a national information policy.

John P. McGowan reviews several issues related to a national information policy from the perspective of the private university library. He identifies a number of critical problems - the difficulties that private institutions encounter in coping with governmental requirements, the year-to-year uncertainty of state and federal funding, the enormous overhead costs of such supportand makes some provocative suggestions for programs that should be supported.

William A. Moffett reviews the attitudes of college librarians on this topic. He finds that they run the gamut, from indifference through distrust and concern to enthusiasm. Moffett also raises an intriguing related issue, having to do with the names and contributions of academic librarians.

I found this group of papers to be stimulating and enlightening on a variety of facets of a very complex issue that is of considerable concern to academic librarians. I am very much pleased that College $b R e$ search Libraries is publishing them. 